\title{
Macrocyclis peruvianus (Gastropoda, Acavidae), an endemic land snail from Chile
}

\author{
Leticia F. da Silva \& José W. Thomé
}

Laboratório de Biologia Parasitária, Pontifícia Universidade Católica do Rio Grande do Sul, Ipiranga 6681, 12-C, sala 282, 90619-900 Porto Alegre, RS, Brazil. (lefosi@gmail.com; josewthome@cnpq.com.br)

\begin{abstract}
Macrocyclis peruvianus (Lamarck, 1822) is a large terrestrial snail which is endemic in Chile. A detailed description of its shell structure, jaw, radula, palial cavity and reproductive system is presented here for the first time.
\end{abstract}

KEYWORDS. Black snail, giant snail, Chile, Caryodinae.

RESUMO. Macrocyclis peruvianus (Gastropoda, Acavidae), um caracol terrestre endêmico do Chile. Macrocyclis peruvianus (Lamarck, 1822) é um grande caracol terrestre endêmico do Chile. Uma descrição detalhada da esculturação de sua concha, rádula, mandíbula, cavidade palial e sistema reprodutor são apresentados aqui pela primeira vez.

PALAVRAS-CHAVE. Caracol negro, caracol gigante, Chile, Caryodinae.

Terrestrial mollusks represent one of the least studied taxa in Chile, despite their importance regarding soil ecology and their existing interrelations with the vegetation (STUARDO \& VeGa, 1985).

The Acavidae family is distributed throughout Madagascar, Sri Lanka, Seychelles, Tasmania, Australia and Chile. A unique monotypic genus occurs in Chile: Macrocyclis peruvianus (Lamarck, 1822). This genus is near four other: Pedinogyra Albers, 1860, Hedleyella Iredale, 1914, Anoglypta Martens (in Albers), 1860, Caryodes Albers, 1850 and form the subfamily Caryodinae after ZiLCH (1960). According to StuARDo \& Vega (1985) is it found from Maule to Chiloé in the central forests and in southern Chile, at the continental region between regions IX and XI; Valdovinos (1999) apud Letelier \& RAmos (2002) informs that the distribution occurs between latitudes $35^{\circ}$ and $45^{\circ} \mathrm{S}$; Hylton Scott (1963) apud Letelier \& RAMOs (2002) mentions that their distribution is restrained to the cordillera region of the Neuquén area and the Negro river, and in the Nahuel Huapi park, being very scarce.

According to LETELIER \& RAMOS (2002) this species is largely associated to forests originally from cordillera or coast, being found among brackens and moss, more frequently in a hepatica of the genus Plagiochila (Plagiochilaceae). The first author founds it exclusively under fallen logs.

LAMARCK (1822) described this species as depressedorbicula shell, strongly umbilicated, straightly wrinkly, fawn reddish, delicately white gray, obtuse spire, sharp peristome, all whorls of the spire whether see towards umbilic. In his description the author doesn't mention where is located the type.

Despite being popularly known, receiving names such as "black snail" for its coloring or "giant snail" for being the largest Chilean snail (Fig. 1), its anatomy remains unknown. A study of the shell, jaw, radula, anatomy of the palial cavity and reproductive system of this species is here presented.

\section{MATERIAL AND METHODS}

The specimens were manually collected by the first author, in the Commune of Cochamó, located in the south of the Llanquihue province in Chile, in January of 2005. The snails were found under fallen logs in the cordillera forest near the Azul lake (Blue lake). During eight hours of searching, three live specimens of M. peruvianus were collected and two juveniles were sighted.

The specimens were distended in distilled water, conserved in $70^{\circ} \mathrm{GL}$ alcohol and incorporated to the collection of the Museu de Ciências e Tecnologia da Pontifícia Universidade Católica do Rio Grande do Sul, Porto Alegre (MCTP).

For the anatomical characterization, two specimens were dissected under a stereomicroscope with an attached camera lucida. The characterization of the anatomy and the respective drawings of the palial cavity and reproductive system were made.

The radulas were prepared according to the methodology proposed by PloEgER \& BREURE (1977) and the preparation of the shells was made with the conventional process. The study of these structures was made from the photomicrographies obtained with a scanning electron microscopy (SEM) at the Centro de Microscopia e Microanálises da Pontifícia Universidade Católica of the Rio Grande do Sul, Porto Alegre (CEMM - PUCRS).

Studied material. CHILE, Llanquihue Province: Commune of Cochamó, 3exs., 20.I.2005, Letícia Fonseca da Silva col. (MCP 8822).

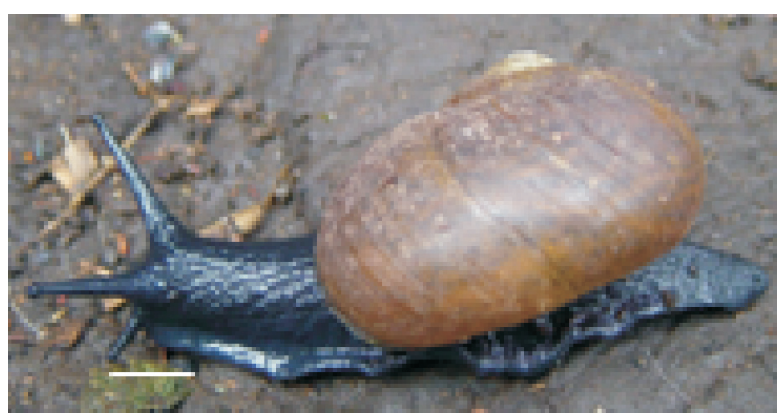

Figure 1. Macrocyclis peruvianus (Lamarck, 1822). Scale, $1 \mathrm{~cm}$. 


\section{Macrocyclis Beck, 1837}

Type species. Helix peruviana Lamarck, 1822 by subsequent designation (Albers, 1850) as H. laxata (Férrusac).

Type locality. Chile.

\section{Macrocyclis peruvianus (Lamarck, 1822)}

(Figs. 1-14)

Shell. Depressed, short spire, $4 \frac{1}{2}-5$ whorls rapidly increasing in size, strongly ovate aperture, aperture's lip is overturned and widened at the bottom (Fig. 2). The initial whorls present discontinuous striae, disposed in spiral, and transversal striae which overlap each other (Figs. 3, 4). Diameter $=45-60 \mathrm{~mm}$.

Radula (Figs. 5-8). Has central, lateral and marginal teeth, presenting a variation among them. As of the disposition of the teeth, the marginal and lateral teeth are slightly inclined towards the central teeth, which have a rectilinear disposition. Unicuspid central teeth, oval and prolonged mesocone with slightly sharp posterior extremity; the posterior region stands out, convex and oval. Unicuspid lateral teeth, narrower mesocone and
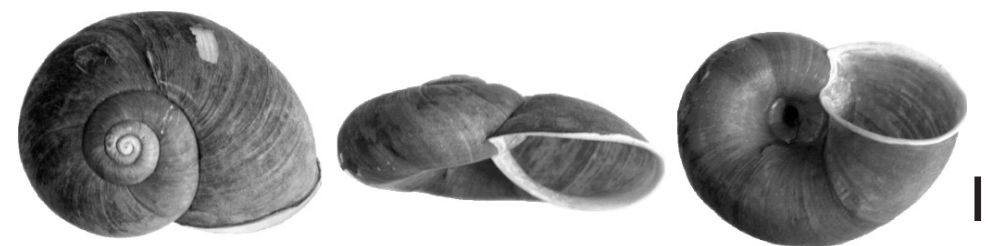

Figure 2. Shell of Macrocyclis peruvianus (Lamarck, 1822) in position, from left to right: dorsal, frontal and ventral. Scale, $1 \mathrm{~cm}$.
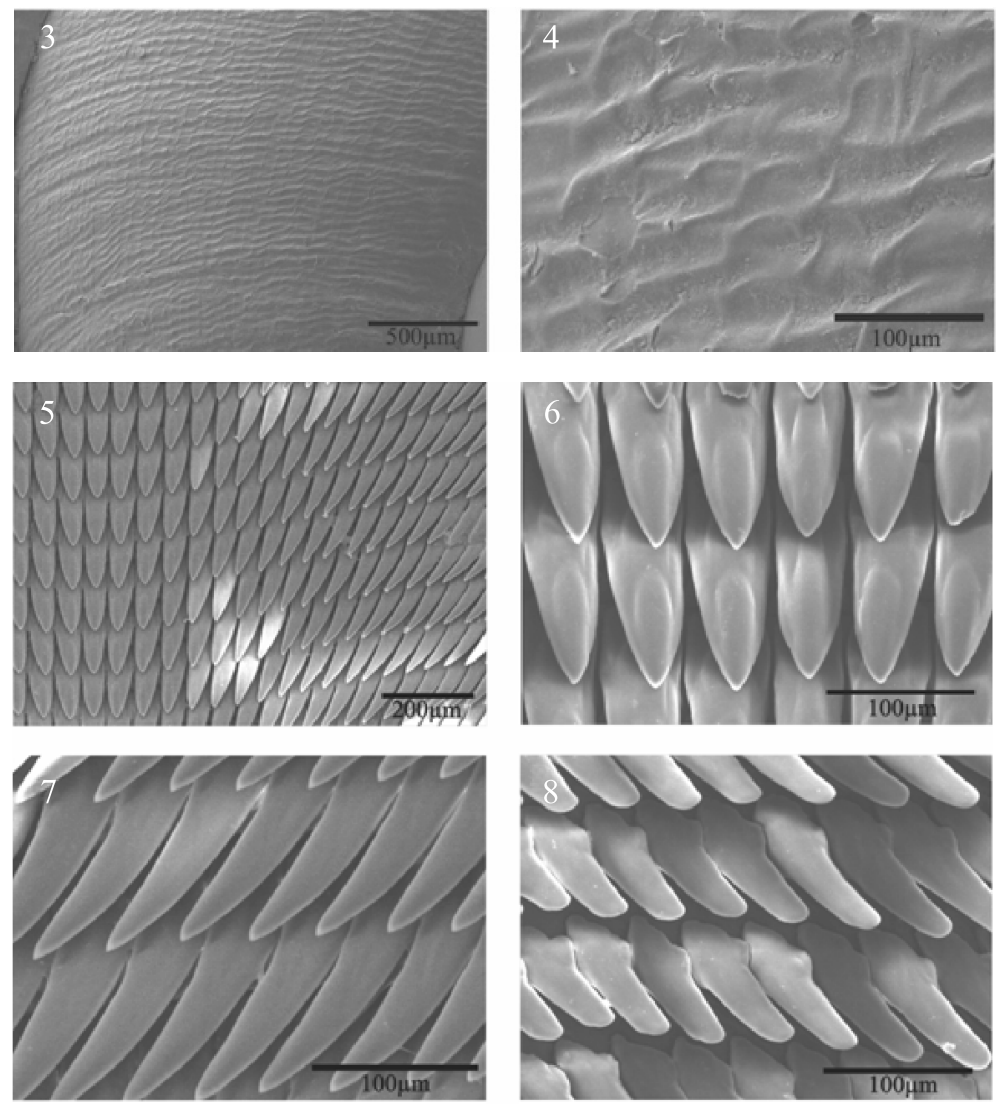

9

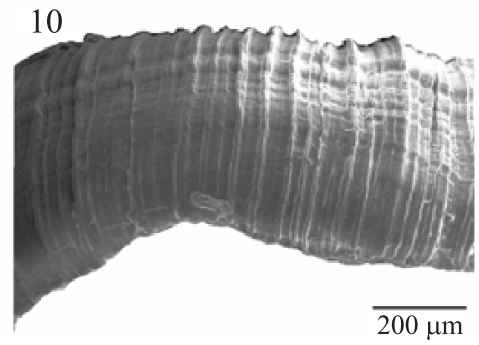

Figures 3-10. Photomicrographies of Macrocyclis peruvianus (Lamarck, 1822). 3, 4, shell: 3, initial whorls; 4, detail of the surface of initial whorls; $5-8$, radula: 5 , teeth disposition; 6 , central teeth; 7 , lateral teeth; 8 , marginal teeth; 9 , 10, jaw: 9 , general view; 10 , detail. 
posterior extremity sharper than central teeth's; it is distinguished by the greater length of the external lateral, resulting in a curve directed to the medium portion of the radula. Unicuspid marginal teeth, with long and rounded mesocone and with traces of endocone. Row-formula of the radula: C10-14/1 + L 16-25/2 + M19-26/2 (adapted from Breure, 1979).

Jaw (Figs. 9, 10). Slightly arched, and does not have ribs; visible transversal growth lines.

Palial cavity (Fig. 11). Shows a pattern of black stains along its entire extension. Triangular kidney, with size corresponding to $1 / 16$ of palial cavity. To the right of the kidney the pericardium is found, involving the ventricle and the auricle, which have similar sizes. The pulmonary vein follows, and parallel to it, towards the kidney, the secondary pulmonary vein is found. The primary ureter, wide and acinous, is on the right anterior side of the kidney. It curves, originating the narrow secondary ureter, which prolongs parallel to the rectum and apparently joins it at about $5 \mathrm{~mm}$ from the anus.
Reproductive system(Figs. 12-14). Triaullic, regarding genital ducts; the diverticulum of the seminal duct, which receives the homologous sperm, has double in caliber than the evertophallus. Ovarioteste formed by tri or bifurcate acinous follicles; the ducts of these follicles converge to the ovulispermioduct which increases in caliber in its final portion, forming the seminal vesicle, which once again becomes thinner and connects to the fertilization complex fitted to the albumin gland. This gland has an elliptic shape and is large and long. Grayish ovispermioduct, with constant epithelial wrinkles throughout its entire extension. On the side opposing the epithelial wrinkles there is a prostatic gland of white yellowish coloring. The ovispermioduct joins the oviduct whose length is similar to the vagina's, which follows it and in its turn joins the atrium, conducting to the genital pore. The thin and delicate gametolytic gland duct prolongs from the vagina, there is a minuscule gametolytic gland on its extremity. Right under the connection of this duct, the vagina receives the diverticulum of the seminal
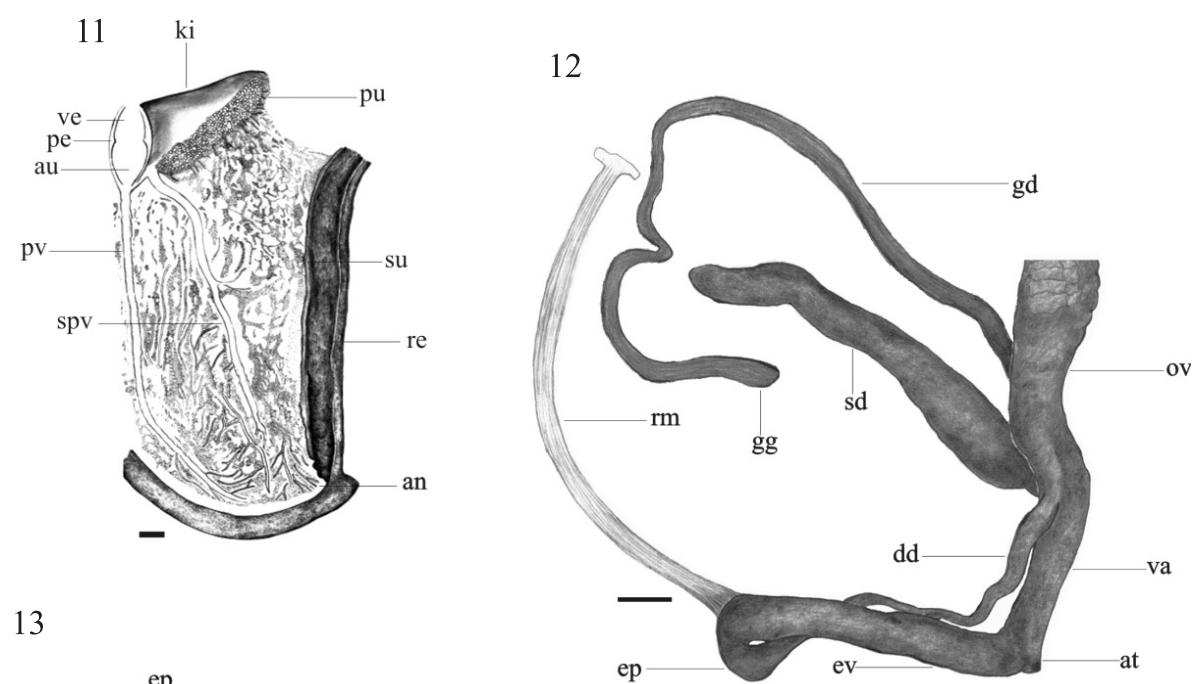

13

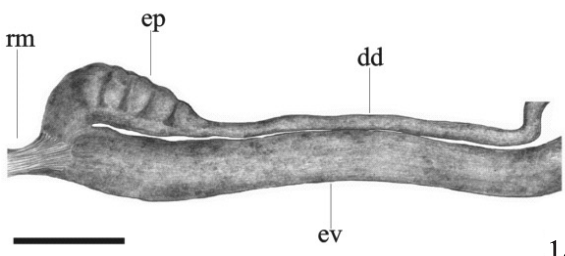

14

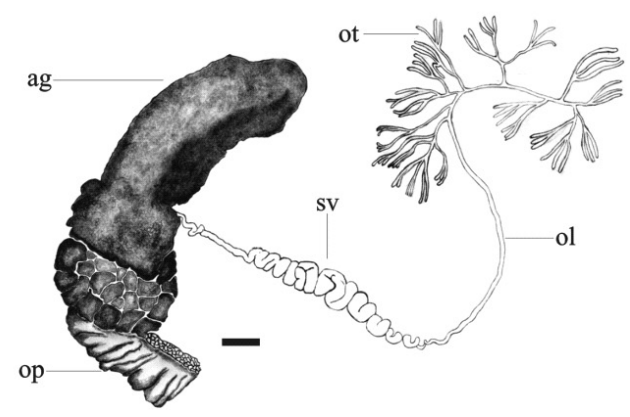

Figures 11-14. Drawings of Macrocyclis peruvianus (Lamarck, 1822). 11, general view of palial cavity (an, anus; au, auricle; ki, kidney; pe, pericardium; pu, primary ureter; pv, pulmonary vein; re, rectum; spv, secondary pulmonary vein; su, secondary ureter; ve, ventricle); 12-14, reproductive system: 12, anterior portion; 13, phallus; 14, detail of the posterior portion (ag, albumin gland; at, atrium; dd, deferent duct; ep, epiphallus; ev, evertophallus; gd, gametolytic gland duct; gg, gametolytic gland; ol, ovulispermioduct; op, ovispermioduct; ot, ovarioteste; ov, oviduct; rm, retractor muscle; sd, diverticulum of the seminal duct; sv, seminal vesicle; va, vagina). Scale, $1 \mathrm{~mm}$. 
duct which has more than double of the caliber of the gametolytic gland duct and about half the length. The deferent duct exteriorizes in the end of the oviduct, inserting itself in the end of the epiphallus. Muscular phallus. Cylindrical, uniform and robust evertophallus, with length three times longer than the epiphallus. The retractor muscle, which is inserted in the end of the evertophallus, presents an extension superior than the evertophallus. The epiphallus is curved above the evertophallus, being initially dilated and progressively decreasing in size.

\section{REFERENCES}

Albers, J. C. 1850. Die Heliceen, nach natürlicher Verwandtschaft systematisch geordnet. Berlin. 262p.
Breure, A. S. H. 1979. Systematics, phylogeny and zoogeography of Bulimulinae (Mollusca). Zoologische Verhandelingen (168): $1-215$

Lamarck, J. B. P. A. DE M. DE. 1822. Histoire naturelle des animaux sans vertèbres. Paris, v.6, partie 2. p.76.

Letelier, S. V. \& Ramos, A. M. L. 2002. Moluscos terrestres y de aguas continentales de la expedición Iniciativa Darwin (19981999), región de Aisén, zona austral de Chile. Boletín del Museo Nacional de Historia Natural 51:185-195.

Ploeger, S. \& Breure, A. S. H. 1977. A rapid procedure for preparation of radulae for routine research with Scanning Electron Microscope. Basteria 41:47-52.

Stuardo, J. \& VeGa, R. 1985. Synopsis of the land mollusca of Chile with remarks on distribution. Studies on Neotropical Fauna and Environment 20:125-146.

Zilch, A. 1960. Euthyneura. In: Wenz, W. ed. Gastropoda. Berlin, Gebrüder Borntraeger. v.2. p.468-471. 